\title{
Crohn's disease of the esophagus: Three cases and a literature review
}

\author{
Ivan Rudolph MD, Franz G oldstein M D, A nthony J DiM arino J r M D
}

I R udolph, F Goldstein, AJ D iM arino Jr. Crohn's disease of the esophagus: Three cases and a literature review. $C$ an J G astroenterol 2001;15(2):117-122. Three cases of esophageal C rohn's disease (CD) are described, each with dysphagia and/or odynophagia caused by esophageal ulceration. A II three patients had associated ileocolitis. O ne patient followed for a prolonged period responded to treatment with sulfasalazine and prednisone. A computer search back to 1967 produced 72 additional cases of esophageal CD. A mong these 75 patients (total), who were, on average, 34 years old, esophageal disease was the presenting disease symptom in 41 patients (55\%). The diagnosis was difficult in 13 patients, in whom no distal bowel disease was detected at the time of initial esophageal presentation. The most common presentation was dysphagia associated with aphthous or deeper ulcerations ( 52 patients). In 11 of these patients, oral aphthous ulcerations were also present. Esophageal stenosis or fistulas to surrounding structures were present in 27 patients and led to surgery in 17 patients. M ost of the unfavourable outcomes were in this group of 27 patients with esophageal complications, including five deaths. Fourteen additional patients required surgery for CD of other areas. R esponses of uncomplicated ulcerative disease of the esophagus tended to be favourable if the medical regimen included prednisone. Clinical patterns of esophageal CD were divided into three categories: ulcerative, stenosing and asymptomatic (acute disease in children).

Key W ords: C rohn's disease; E sophageal disease

\section{Trois cas de maladie de C rohn de l'œsophage et examen de la documentation}

RÉSU MÉ : Voici trois cas de maladie de Crohn (MC) de l'œsophage caractérisée par une dysphagie et/ou une odynophagie causée par une ulcération œsophagienne. Les trois patients présentaient également une iléo-colite. Le suivi prolongé d'un patient a montré que ce dernier avait bien réagi au traitement à la sulfasalazine et à la prednisone. U ne recherche informatisée des dossiers depuis 1967 a permis de relever 72 cas de M C de l'œsophage. U n trouble de l'œsophage a été le premier signe de la maladie chez 41 des 75 patients ( $55 \%$ ), âgés en moyenne de 34 ans. Le diagnostic a été difficile à poser chez 13 d'entre eux étant donné qu'aucune maladie intestinale distale n'avait été décelée au moment de l'apparition du premier signe de trouble œsophagien. La manifestation la plus courante a été une dysphagie associée à une ulcération aphteuse ou profonde (52 patients); onze souffraient également d'aphtes buccaux. Vingt-sept patients présentaient une sténose œsophagienne ou des fistules et 17 d'entre eux ont dû être opérés. La plupart des résultats négatifs, dont cinq morts, ont été observés dans le groupe de patients présentant des complications œsophagiennes. Q uatorze autres patients ont été opérés pour une $\mathrm{MC}$ touchant d'autres régions. Le traitement de la forme non compliquée de l'ulcération œsophagienne semblait donner de bons résultats si celui-ci comprenait de la prednisone. Les signes cliniques de la M C de l'œsophage ont été divisés en trois catégories : ulcères, sténose et absence de symptômes (maladie aiguë chez les enfants).

T he prevalence of esophageal involvement in Crohn's disease (CD) has been estimated in the literature to be between $1 \%$ and $2 \%$ (1). However, the pediatric literature has reported a prevalence of $20 \%$ to $40 \%$ when all patients

were prospectively surveyed by means of esophagogastroduodenoscopy (EGD) during the acute phase of CD (2). $C$ ase reports are typically brief, and not all questions can be answered by reviewing them. Three cases of esophageal CD

T his mini-review was prepared from a presentation made at the 1998 meeting of the Bockus International Society of G astroenterology,

G raz, A ustria, A ugust 31 to September 3, 1998

D ivision of $\mathrm{G}$ astroenterology, T homas J efferson U niversity, Philadelphia, Pennsylvania, U SA

Correspondence and reprints: Dr I Rudolph, D ivision of G astroenterology and H epatology, Thomas J efferson U niversity, 132 South 10 th Street,

480 M ain Building, Philadelphia, Pennsylvania 19107-5244, U SA. Telephone 215-955-8900, fax 215-955-0872,

e-mail franz.goldstein@mail.tju.edu

Received for publication July 6, 1999. A ccepted July 12, 1999 


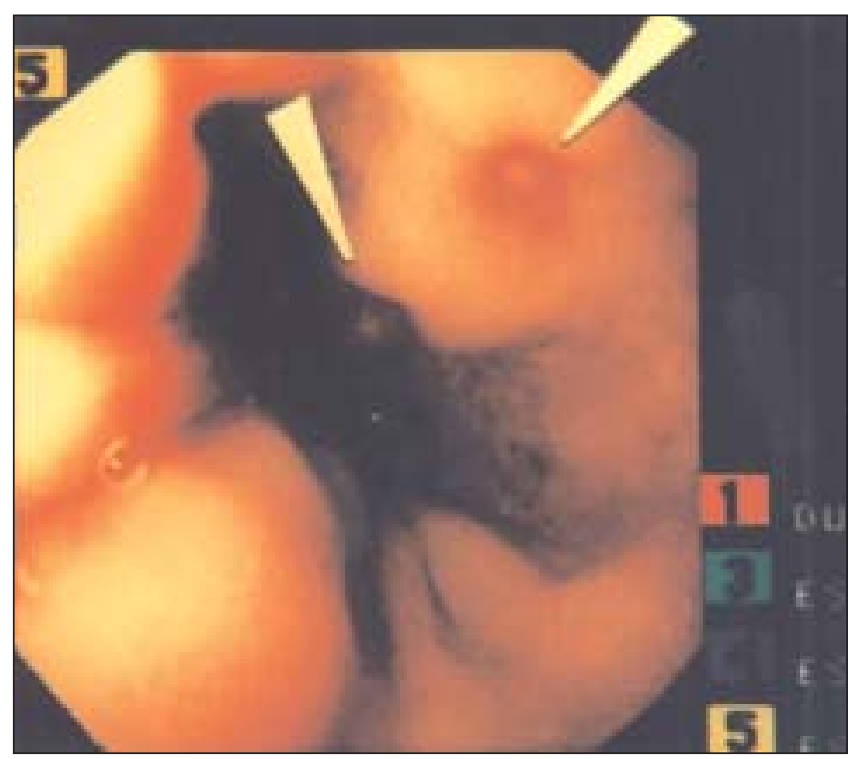

Figure 1) Discrete small ulcerations in the distal esophagus of the patient described in case $1 . M$ arkers indicate two ulcers

recently encountered in the authors' practices are described, together with a review of the pertinent literature.

\section{CASE 1}

A 24-year-old married woman was seen in February 1998; her chief complaint was odynophagia. She had suffered from prolonged heartburn. Treatment with $\mathrm{H}_{2}$-receptor blockers, and later with proton pump inhibitors, produced only minor symptom relief. Subsequently, odynophagia developed, brought on by swallowing any food or even saliva. Avoidance of spicy foods produced minimal benefit. Past medical history recalled by the patient included 'functional' gastrointestinal problems in 1986, when the patient was 12 years old. U nrelated events also recalled included bouts of cystitis, and asthma treated with oral prednisone and an albuterol inhaler. On physical examination, the patient appeared well developed and nourished, vital signs were normal and general examination failed to show any abnormalities. Because of the odynophagia, EGD was performed. EGD revealed three distinct esophageal ulcers, each appearing as a sharply demarcated, red, approximately $5 \mathrm{~mm}$ round area in the lower esophagus surrounded by normal-appearing mucosa (Figure 1). The Z-line was distinct without clinically apparent esophagitis or stricture. The stomach and duodenum appeared normal. Biopsies from the lower esophagus revealed dense lymphocytic infiltrates in several areas and ulcerations in others. Granulomas were not found.

The patient's mother recalled that her daughter had been suspected of having CD in 1986. Records and x-rays were retrieved. The patient had presented in 1986 with diarrhea and abdominal pain. Barium contrast studies of the gastrointestinal tract were reviewed and showed a distinct segment of ileocolitis involving about $6 \mathrm{~cm}$ of the terminal ileum and $3 \mathrm{~cm}$ of the adjacent cecum. The EGD in

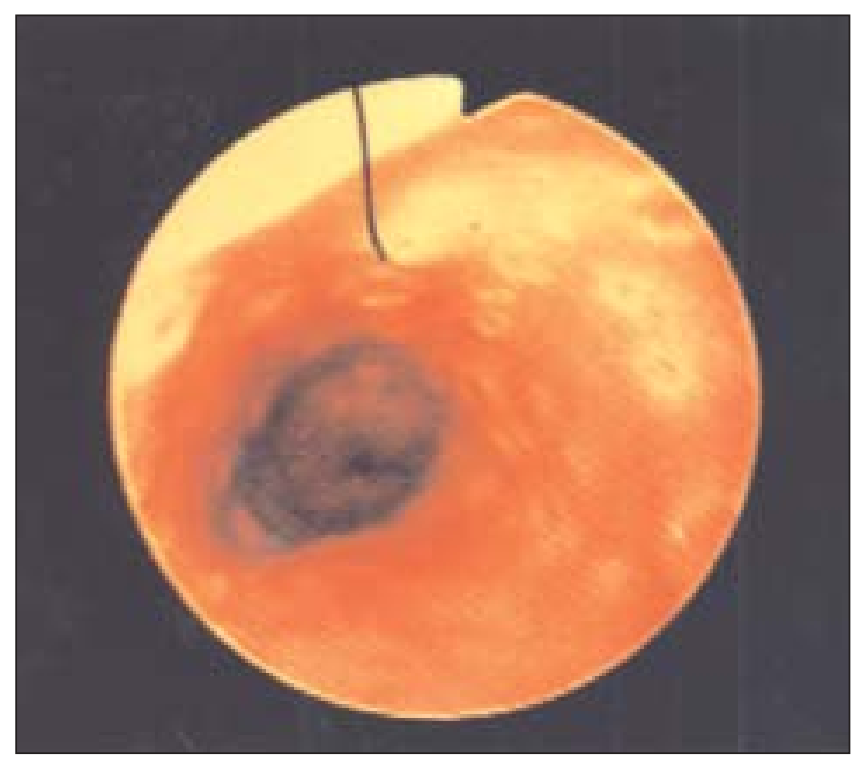

Figure 2) M ultiple aphthous ulcers in the mid- and distal esophagus of the patient described in case 2

1986 also showed antral gastritis, with biopsies confirming nonspecific inflammation of the prepyloric area with $\mathrm{H}$ elicobacter pylori positivity. Treatment with ampicillin seemed to help. Follow-up radiographs in 1989 showed partial improvement of the ileal changes. R epeat radiographs obtained in 1998 showed minimal residual scarring of the terminal ileum. Treatment was initiated with mesalamine, but the patient was lost to follow-up before the response to treatment could be evaluated.

The interpretation of events from 1986, 1989 and 1998 suggests that they were due to $C D$, and that the recent predominant problem is esophageal $C D$ with multiple ulcers and corresponding symptoms.

\section{CASE 2}

A 28-year-old married woman presented in A pril, 1991 with three weeks of abdominal cramps and up to six watery stools per day. Five days before her visit, she developed a sore throat, and her husband, who was a physician, noted aphthous ulcers in her mouth. The patient developed dysphagia and odynophagia by the time of her evaluation. She had fevers with temperatures of up to $102^{\circ} \mathrm{C}$. Past medical history included uveitis treated at a university clinic with steroid eye drops.

On examination, the patient's blood pressure was $100 / 70 \mathrm{mmH} g$ and her pulse was 112 beats/min. $0 \mathrm{n}$ the hard palate and buccal surfaces, multiple white papules - some ulcerated - were noted. The remainder of the examination was unremarkable, except for a grade 2 systolic murmur at the apex and mild, lower to mid-abdominal tenderness. $\mathrm{On}$ the EGD, multiple small aphthous ulcerations on slightly el evated bases were noted, which were similar to the ones in the mouth and measured from $2 \mathrm{~mm}$ to $6 \mathrm{~mm}$ in diameter (Figure 2). Similar lesions were also found diffusely distributed in the stomach and proximal duodenum. The duodenal loop was normal. Biopsies and brushings taken from the 
ulcers failed to show viral inclusions but did show acute and chronic superficial gastritis and esophagitis, with some granulation tissue and scattered ulcerations. Flexible sigmoidoscopy, done at the same time, showed erythema and shallow irregular ulcerations scattered over the distal $35 \mathrm{~cm}$. Biopsies reveal ed acute and chronic inflammation with crypt abscesses, consistent with inflammatory bowel disease. $\mathrm{G}$ ranuloma formation in submucosal lymphoid aggregates was suggested.

The patient was treated with sulfasalazine $2 \mathrm{~g} /$ day and prednisone $40 \mathrm{mg} /$ day, followed by a dramatic response the disappearance of dysphagia within a few days and improvement in the diarrhea. $W$ hen the patient was seen in the office three weeks later, the aphthous ulcerations of the mouth were no longer seen, and she reported to be free of dysphagia and diarrhea. Stool cultures and examinations for ova and parasites were reported to be negative. Prednisone was tapered to nothing over a 10-week period, but sulfasalazine was continued. Pancolonoscopy, done in this healing phase, showed mild erythema in the right colon and nodularity in the distal $30 \mathrm{~cm}$ of the left colon. Biopsies from the right colon showed acute and chronic colitis, while biopsies from the left colon showed focal lymphoid aggregates with early changes of granuloma.

The patient became pregnant shortly after going into remission and delivered healthy twins in January, 1993. Sulfasalazine was stopped seven months later, and the patient remained well for another 10 months, when she developed recurrent diarrhea. She again responded to sulfasal azine and prednisone, the latter being tapered over the next two months. With sulfasalazine alone, the patient remained in remission for two years. Sulfasal azine was again stopped, followed by another relapse four months later. Both prednisone and sulfasalazine were restarted with a prompt response. After tapering prednisone again, the patient continued in remission while on sulfasal azine alone for the next eight months of observation. None of the relapses were accompanied by esophageal symptoms.

\section{CASE 3}

A 42-year-old man was evaluated in a gastrointestinal clinic for a 20-year history of Crohn's disease, initially involving the terminal ileum. The diagnosis was established with exploratory laparotomy for what was thought to be acute appendicitis in 1979, at age 22 years. $\mathrm{H}$ is initial presentation was severe right lower quadrant pain, with elevation of his white blood cell count to 14,000 . A fter a period of observation, it was thought that he had acute appendicitis and, at the time of laparotomy, was found to have congestion and thickening of the terminal ileum with a large thickened mesentery and an enlarged mesenteric lymph node. Pathology revealed increased lymphocytes with no granulomas in the mesenteric lymph nodes and a normal appendix. A subsequent small bowel series revealed $5 \mathrm{~cm}$ to $6 \mathrm{~cm}$ of terminal ileal narrowing, consistent with C rohn's disease.

In 1984, the patient developed perianal burning and pain with defecation. He had recurrent fissures involving the anal sphincteric region and was seen by his attending gastroenterologist; he was subsequently referred to a colorectal surgeon. A fissure from the C rohn's disease was noted, and local care, incision and drainage were judiciously performed over the next several years.

In 1985, an air contrast barium enema reveal ed scarring of the ileocecal valve with aphthous ulcerations consistent with Crohn's disease.

In 1986, the patient described dysphagia, particularly with solid foods, and was evaluated by a gastroenterologist with upper endoscopy. Findings at that time revealed an exudative distal esophageal mucosa with multiple small ulcerations. The amount of esophageal involvement was approximately $2 \mathrm{~cm}$ to $3 \mathrm{~cm}$ in length. $\mathrm{He}$ was treated with high dose $\mathrm{H}_{2^{-}}$ receptor antagonists without improvement. $\mathrm{H}$ is esophageal ulcerations were re-evaluated by two subsequent gastroenterologists - all within an 18-month period. Despite intensive antisecretory therapy, the esophageal ulcerations persisted. Several biopsies of the area revealed lymphocytic infiltrate with occasional eosinophils. No granulomas were identified. $\mathrm{He}$ initially required balloon esophageal dilation, and periodically since 1986, he has required Maloney bougienage therapy for recurrent dysphagia and odynophagia. $\mathrm{H}$ is esophageal ulcerations persisted despite proton pump inhibitor therapy in the form of omeprazole $40 \mathrm{mg}$ bid, $\mathrm{H}_{2^{-}}$ receptor antagonists in the form of ranitidine or famotidine $40 \mathrm{mg}$ bid, and antacids. The dysphagia and perianal discomfort with defecation improved with azathioprine therapy $300 \mathrm{mg} /$ day. H owever, he developed severe leukopenia, and this medication was withdrawn.

Intermittent therapy with metronidazole, ciprofloxacin, corticosteroids and 5-aminosalicylic acid preparations have not significantly altered the patient's recurrent symptoms of odynophagia and dysphagia for solids. He requires periodic esophageal dilations with Maloney tapered bougies. Successful dilations are completed to an approximately $1.6 \mathrm{~cm}$ esophageal lumen, performed approximately every three to six months, in conjunction with therapy to decrease acid secretion in the form of proton pump inhibitors, $\mathrm{H}_{2^{-}}$ receptor antagonists and sucral fate suspension.

$\mathrm{He}$ is relatively asymptomatic from a lower gastrointestinal viewpoint, having approximately one or two formed bowel movements per day.

\section{LITERAT URE REVIEW}

Review of the English language literature using a computer search of MEDLINE for the years 1967 to 1998 yielded reports for 72 patients with esophageal CD (1,3-40). A fter adding the present three cases, data of all 75 patients were tabulated by age, sex, whether CD at other sites predated the esophageal presentation and which sites, in addition to the esophagus, were involved. Data were also tabulated on the endoscopic and radiographic appearance of the esophagus, and whether granulomas were found in biopsies and other tissue specimens. Finally, available data on medical and surgical treatments and clinical outcome were analyzed. 
TABLE 1

Distribution of Crohn's disease with initial presentation of esophageal disease

\begin{tabular}{lcc}
\hline $\begin{array}{l}\text { Distribution of } \\
\text { Crohn's disease }\end{array}$ & $\begin{array}{c}\text { No previous history } \\
\text { of Crohn's disease } \\
(\mathbf{n}=\mathbf{4 1})^{*}\end{array}$ & $\begin{array}{c}\text { Previous history of } \\
\text { Crohn's disease } \\
(\mathbf{n}=\mathbf{3 3})\end{array}$ \\
\hline Colon & 22 & 24 \\
Small bowel & 22 & 26 \\
Gastroduodenal & 12 & 7 \\
Oral & 11 & 9 \\
\hline
\end{tabular}

*One case history indeterminate for additional Crohn's disease

\section{RESU LT S}

A mong the 75 patients reviewed, including the three present cases, 34 were male and 41 female - an insignificant difference. The average age of the patients at diagnosis of esophageal CD was 34 years; this average masks a substantial number of patients diagnosed in childhood, most of whom were reported relatively recently. In 13 patients (17.5\%), the initial diagnosis of CD was made by the presence of esophageal manifestations alone. In an additional 28 patients $(37.8 \%)$, esophageal involvement, together with involvement more distally in the gut, was present on initial diagnosis. A mong the 13 patients with esophageal disease only on presentation, two developed more distal bowel involvement during the four years of follow-up $(9,25)$. W ith the short follow-ups available in many cases, it was not possible to determine whether subsequent flare-ups were associated with more distal bowel disease.

The distribution of involved segments of the gut in patients with and without prior diagnosis of $C D$ showed no significant differences in disease distribution (Table 1). Extraintestinal manifestations (not listed) were present in 20 patients ( $27 \%)$, and involved the eyes, joints and skin.

The coexistence of oral and esophageal lesions was striking. Of the 20 patients with oral disease, 11 had similarly appearing aphthous ulcers in the esophagus. The remaining nine patients had variable esophageal lesions ranging from deeper ulcerations to strictures. Table 2 lists the combined endoscopic and radiographic appearance of the esophageal CD in the group of 75 patients. The largest number of patients presented with aphthous or deeper ulcerations; smaller numbers presented with nodularity or erythema, strictures, fistulas and, in two instances, pseudopolyps $(13,19)$.

The histology of esophageal tissue recovered from 69 patients showed acute and chronic inflammation, ulcerations, and occasional fibrosis and transmural involvement in patients who had surgical, full-thickness biopsies. Classic granulomas were found in 27 patients (39\%).

Esophageal complications in the form of stenosis, fistula or both were present in 27 patients; their mean age was 47 years - considerably older than the mean age of the entire group. This suggests that these patients had longstanding disease progressing to the complications listed. In four
TABLE 2

Gross appearance of esophageal Crohn's disease in 75 patients*

\begin{tabular}{|c|c|}
\hline Category $^{\dagger}$ & Patients with characteristic (n) \\
\hline Aphthous ulcers & 32 \\
\hline Deep ulcerations & 20 \\
\hline Nodularity and erythema & 15 \\
\hline Pseudopolyps & 2 \\
\hline Stricture & 24 \\
\hline Fistula & 9 \\
\hline
\end{tabular}

*Total of more than 75 indicates that there was more than one gross characteristic in the same patient; ${ }^{\dagger}$ Categories based on endoscopic and radiological appearance

patients, fistulous drainage was documented to a pleural cavity or bronchus $(15,16,25,32)$. Seventeen of the 27 patients with fistulas and/or stenosis required surgery. Of these, 13 were improved while four failed to improve, including three who died $(34,40)$. Of the 10 remaining patients treated medically, five improved and five failed to improve, including two deaths $(16,32)$. A mong the 75 patients (total) there were nine deaths, and only four were due to causes other than esophageal complications, including fulminant disease with bowel perforation (34), multiple resections and their nutritional consequences $(28,31)$, and sepsis (10).

Seventeen of the 75 patients were treated with surgery alone. Fourteen additional patients underwent surgery together with various medical interventions. Thirty-five were treated with medical or pharmacological therapy alone. In nine cases, no details of therapy were provided. A mong the 49 patients treated medically, 43 received corticosteroids alone or in combination with aminosalicylates, and six received aminosalicylates only. Ten patients were al so treated with other modalities including bougienage, acid suppressants or 6-mercaptopurine (five patients). Steroid treatment generally produced short term improvement, but long term results could not be noted. Responses to drugs other than steroids or immunomodulators were usually poor, although, in case 2 in the present report, sulfasalazine seemed to provide some benefit. Some patients showed symptomatic improvement with acid suppression and/or bougienage, but no esophageal healing could be seen.

Eighteen patients had bowel surgery either before or after the discovery of esophageal disease. Resolution of bowel disease and improvement in unresected esophageal disease was reported in one patient (30). A nother (18) had esophageal improvement while on steroids, which were tapered four months postoperatively. In 16 other patients, esophageal disease developed after bowel resection or esophageal disease progressed despite segmental resection of intestinal CD $(8-10,13,16,19,20,25,28,29,31-34)$.

\section{DISC U SSION}

The esophagus is among the least common segments of the digestive tube involved in $C D$. We were able to find only 72 cases reported in the literature and added the three present 
cases. Very few cases were reported before 1967, although the initial description of esophageal $C D$ is attributed to Franklin and Taylor in 1950 (41). U ndoubtedly, many more cases encountered have not been reported. W ith the wider use of upper gastrointestinal endoscopy in recent years, and with prospective studies in patients with $C D$, esophageal involvement has been observed in up to $43 \%$ of children with CD (2). Lenaerts et al (42) surveyed 230 children and adolescents with $C D$ for an average of 6.6 years. Thirty per cent of these had disease of the esophagus, stomach or duodenum. Although 69 of the 230 patients had upper gastrointestinal symptoms, 13 had normal x-rays, and only endoscopy revealed lesions compatible with CD. Korelitz et al (43) performed routine upper endoscopies and biopsies of the esophagus, stomach and duodenum in 45 patients with $C D$, and normal upper gastrointestinal $x$-rays. They found diagnostic biopsies in 11 patients and nonspecific microscopic changes in 19 patients; among the patients with abnormal biopsies were 11 patients with endoscopically normal-appearing mucosa. These studies illustrate the frequent presence of upper gastrointestinal lesions in the absence of symptoms and sometimes in the absence of endoscopic abnormalities. There seems to be a major difference in the prevalence of esophageal $C D$ between children and adults. Because CD is a chronic, often lifelong disease, the difference in the frequency of esophageal involvement between children and adults invites speculation as to the cause of this discrepancy. M any patients with esophageal $C D$ were reported to have aphthous ulcerations, generally regarded as very early manifestations of $C D$ and often observed at onset of the disease. With later progression of the disease, the aphthous ulcers of the esophagus may disappear. H owever, in the present literative review, CD of the colon, ileum or gastroduodenal segment preceded esophageal involvement in 33 patients by up to 24 years, perhaps showing in yet another way the wide range of manifestations of this baffling disease. When esophageal $C D$ was observed in adults, it often presented with stenoses and fistulas, which are generally considered complications of longstanding $C D$.

Most patients with esophageal CD present with odynophagia and/or dysphagia. Bleeding and fistulization occur rarely; however, when present, they indicate a more threatening aspect of the disease. Fistulas to bronchi or pleural spaces usually require surgical intervention, and carry a substantial risk of morbidity and mortality. Three deaths occurred in the group of 17 patients who were operated on for esophageal fistulas and/or stenosis, and two deaths occurred in patients treated medically for this complication. O nly four additional deaths occurred among the entire group of 75 patients reviewed. The use of the newer expandable metal stents may decrease the need for surgery, and complications could perhaps be reduced.

The diagnosis of esophageal CD can be suspected if dysphagia or odynophagia is present, but these are not specific for $C D$. In patients with $C D$ known to exist in other gastrointestinal segments, the right diagnosis should be sug-
TABLE 3

Differential diagnosis of Crohn's disease

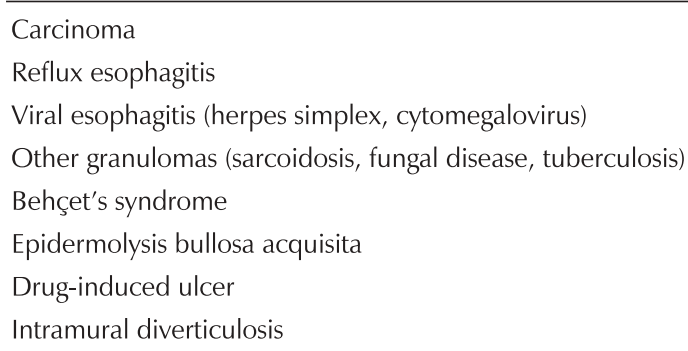

gested but needs confirmation by means of endoscopy and tissue examination. In most cases, endoscopic findings alone are not specific; histological changes, more likely than not, fail to show granulomas and can only be considered compatible with $C D$. Yet with the exclusion of other specific diagnoses, and in the proper clinical setting, the diagnosis reasonably can be made with these tests.

The differential diagnosis of CD of the esophagus is tabulated in Table 3. In the presence of stenosis, severe reflux esophagitis or carcinoma ranks high among diagnostic possibilities. The additional presence of fistulas would especially suggest malignancy. A phthous or other superficial ulcerations would require differentiation from viral infections, especially the herpes simplex virus and the cytomegalovirus; single or multiple ulcers would also have to be differentiated from drug-induced lesions. Behçet's syndrome would pose diagnostic difficulties in areas where this disease is common (eg, Turkey - it is rarely encountered in the U nited States). In this syndrome, overlapping involvement of the eyes, mouth, skin, joints and gastrointestinal tract occurs. Two cases of Behçet's syndrome involving the esophagus and ileum were reported by V lyman and M oskowitz (44). Two other cases of colonic disease indistinguishable from $C D$ were also reported $(45,46)$. Epidermolysis bul losa acquisita is another autoimmune disease that can be associated with esophageal strictures. Thirteen cases have been reported in association with CD (47). The diagnosis is made by immunoelectron microscopy of the skin lesions demonstrating immunoglobulin $\mathrm{G}$ and $\mathrm{C}-3$ deposits.

There is little information on appropriate treatment. No controlled therapeutic trials have been reported dealing with esophageal $C D$, and its relative infrequency would make such trials difficult to perform. Observational data suggest therapeutic benefits primarily from corticosteroids given over short periods of time. Virtually all pharmacological agents used for inflammatory bowel disease have been used in the treatment of $C D$, including aminosalicylates and immunomodulators. Removal of a stenotic segment of esophagus refractory to medical treatment and frequent bougienage were the most common reasons for surgery among the patients reviewed. The relative frequency of surgery and its high complication rate are noted. Surgical resections of diseased distal gut segments failed to affect the course of esophageal CD in 16 of 18 patients. 
Prognosis on medical therapy was addressed by D'H aens et al (3), who followed 14 patients for an average of six years. Twelve patients were treated with prednisone and two were treated with aminosalicylates plus antibiotics. In eight patients, there was complete healing of the esophageal disease despite further exacerbations of $C D$ elsewhere. These data, as well as the higher prevalence of esophageal CD in children compared with adults, suggest that spontaneous improvement of esophageal CD occurs commonly.

A nalysis of the collected data suggests that esophageal $C D$ should be categorized into three broad clinical presentations. The most common presentation is dysphagia or odynophagia accompanied by aphthous or deeper ulcerations, usually associated with acute exacerbations of the $C D$. Patients may also present with strictures (stenosis) with or without fistula, usually at an older age and with a history of chronic disease. Patients with esophageal $C D$ may be asymptomatic but frequently have symptomatic $C D$ in more distal gut segments. This would include patients with normal endoscopy but abnormal histology. This presentation would explain the high prevalence of esophageal $C D$ reported in children with symptomatic CD distally, but undergoing EGD and biopsy.

ACKN OWLEDGEMENT S: The authors thank Dr Stuart Eisenberg for providing the information for case 2 and Celeste $\mathrm{H}$ odges, Librarian, for providing the literature searc

\section{REFEREN CES}

1. Weinstein T, Valderrama E, Pettei M, Levine J. Esophageal C rohn's disease: M edical management and correlation between clinical endoscopic and histologic features. Inflamm Bowel Dis 1997;3:79-83.

2. Ruuska T, Vaajahlati P, A rajarvi P, M aki M. Prospective evaluation of upper gastrointestinal mucosal lesions in children with ulcerative colitis and Crohn's disease. J Pediatr G astroenterol N utr 1994;19:181-6.

3. D'H aens $G$, Rutgeerts $P, G$ eboes $K$. The natural history of esophageal Crohn's disease. G astrointest Endosc 1994:40:296-300.

4. Fernandez CM , Ledo L, C unquiero R. Early esophageal C rohn's disease: A n endoscopic appearance. G astrointest Endosc 1990;36:303-4.

5. Treem W R, Ragsdale BD. Crohn's disease of the esophagus: A case report. J Pediatr G astroenterol N utr 1988;7:451-5.

6. Degryse HR, Deschepper A M. A phthoid esophageal ulcers in Crohn's disease of the ileum and colon. Gastrointest Radiol 1984;9:197-201.

7. Tishler JM, H elman CA. Crohn's disease of the esophagus. J Can A ssoc Radiol 1984;35:28-30.

8. Gray RR, Louis EL, G rossman H. Crohn's disease involving the proximal stomach. Gastrointest Radiol 1985;10:43-5.

9. Rowe PH, Taylor PR, Sladen G E. Cricopharyngeal Crohn's disease. Postgrad M ed J 1987;63:1101-2.

10. Davidson JT, Sawyers JL. C rohn's disease of the esophagus. A m Surg 1983;49:168-72.

11. Taskin V, VonSohsten R, Singh B. Crohn's disease of the esophagus. A m J Gastroenterol 1995;90:1000-1.

12. H owden FM, M ills LR, Rubin JW. Crohn's disease of the esophagus. A m Surg 1994;60:656-60.

13. Walker RS, Breuer RJ, Victor T. C rohn's esophagitis: A unique cause of esophageal polyposis. G astrointest Endosc 1996;43:511-5.

14. Kuboi H, Yashiro K, Shindou H. Crohn's disease in the esophagus: Report of a case. Endoscopy 1998;20:118-21.

15. M athis G, Sutterlutti G, Dirschmid K. C rohn's disease of the esophagus: Dilation of stricture and fibrin sealing of fistulas. Endoscopy 1994;26:508.

16. Steel A, Dyer N H, M atthews HR. Cervical Crohn's disease with oesophago-pulmonary fistula. Postgrad M ed J 1988;64:706-9.
17. Estrin H M , H ughes RW. O ral manifestations in Crohn's disease: Report of a case. A m J Gastroenterol 1985;80:352-4.

18. Borum M L, A lbert M B. A n unusual case of esophageal Crohn's disease and review of the literature. Dig Dis Sci 1997;42:424-6.

19. Cockey BM, Jones B, Bayless T M, Shauer A B. Filiform polyps of the esophagus with inflammatory bowel disease. A m J Radiol 1985;144:1207-8.

20. M affei VJ, Zaatari GS, M CG arity W C, M ansour KA . C rohn's disease of the esophagus. J Thorac Cardiovasc Surg 1987;94:302-11.

21. Case records of M assachusetts $G$ eneral H ospital. N Engl J M ed 1995;333:1066-72.

22. Freedman PG, Dieterich DT, Balthazar EJ. Crohn's disease of the esophagus: $C$ ase report and review of the literature. A m J G astroenterol 1984;79:835-8.

23. Freson M, Kottler RE, W right JP. C rohn's disease of the esophagus: A case report. S A fr M ed J 1984;66:417-8.

24. O akley JR, Lawrence DA, Fiddian RV. Sarcoidosis associated with Crohn's disease of ileum, mouth, esophagus. J R Soc M ed 1983;76:1068-71.

25. G haremani G G, G ore RM, Breuer RI, Larson RH. Esophageal manifestations of $C$ rohn's disease. $G$ astrointest Radiol 1982;7:199-203.

26. G ohel V, Long B, Richter G. A phthous ulcers in the esophagus with Crohn's disease. A JR A m J Roentgenol 1981;137:872-3.

27. $M$ annell $A, H$ amilton DG. C rohn's disease of the esophagus: $A$ case report. A ust N Z J Surg 1980;50:303-8.

28. Bianco L, Sategna-G uidetti C, Colombatti G. C rohn's disease of the upper gastrointestinal tract. Panminerva M ed 1981;23:11-16.

29. Lee C S, M angla JC, Lee SSC. C rohn's disease in Barrett's esophagus. A m J G astroenterol 1978;69;646-54.

30. M iller LJ, Thistle JL, Payne W S. C rohn's disease involving esophagus and colon. Mayo Clin Proc 1977:52:35-8.

31. Werthamer S, Zak FG, M ihailos P. G ranulomatous esophagitis (C rohn's disease). N Y State J M ed 1976;76:938-40.

32. Cynn WS, Chon H, Gureghian PA. Crohn's disease of the esophagus. A m J Roentgenol Radium Ther N ucl M ed 1975;125:359-64.

33. Case records of M assachusetts $G$ eneral H ospital. N Engl J M ed 1973;289:147-53.

34. H uchzermeyer H, Paul F, Seifert E. Endoscopic results in 5 patients with Crohn's disease. Endoscopy 1977;8:75-81.

35. Dyer N H, Cook PL, Kemp H arper RA. Esophageal stricture associated with Crohn's disease. G ut 1969;10:549-54.

36. Turina M, Schamaun M, W aldvogel W. C rohn's disease of the esophagus. G er M ed M on 1969;14:49-50.

37. G elfand M D, Krone CL. Dysphagia and esophageal ulceration in C rohn's disease. G astroenterology 1968;55:510-14.

38. M adden JL, Ravid JM , H adad JR. Regional esophagitis: A specific entity simulating C rohn's disease. A nn Surg 1969;170:351-68.

39. Legge DA, C arlson HC, Judd ES. Roentgenographic features of regional enteritis of the upper gastrointestinal tract. A $\mathrm{m} J$ Roentgenol Radium Ther N ucl Med 1970;110:355-60.

40. LiVolsi VA, Jaretzki A III. G ranulomatous esophagitis: A case of C rohn's disease limited to the esophagus. G astroenterology 1973;64:313-19.

41. Franklin RH, Taylor S. N onspecific granulomatous (regional) esophagitis. J Thorac Cardiovasc Surg 1950;19:292-7.

42. Lenaerts $C$, Roy $C C$, Vaillancourt $M D$, Weber $A M$, M orin $C L$, Seidman $\mathrm{E}$. High incidence of upper $\mathrm{GI}$ tract involvement in children with Crohn's disease. Pediatrics 1989;83:777-81.

43. Korelitz BI, W aye JD, Kreuning J, Sommers SC, Fein HD, Beeber J. $C$ rohn's disease in endoscopic biopsies of gastric antrum and duodenum. A m J G astroenterol 1981;76:103-9.

44. V lyman W J, M oskowitz PS. R oentgenographic manifestations of esophageal and intestinal involvement in Behcet's disease in children. Pediatr Radiol 1981;10:193-6.

45. Tolia V, A bdullah A, Thirumoorthi M C. A case of Behcet's disease with intestinal involvement. A m J G astroenterol 1989;84:322-5.

46. Kallinowski B, N oldge G, Steihl A. C rohn's disease with Behcet's syndrome-like appearance. Z G astroenterol 1994;32:642-4.

47. Schattenkirchner S, Lemann W, Prost C. Localized epidermolysis bullosa acquisita of the esophagus in a patient with Crohn's disease. A m J G astroenterol 1996;91:1657-9. 


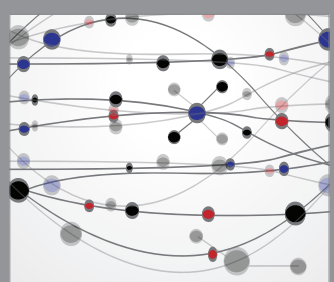

The Scientific World Journal
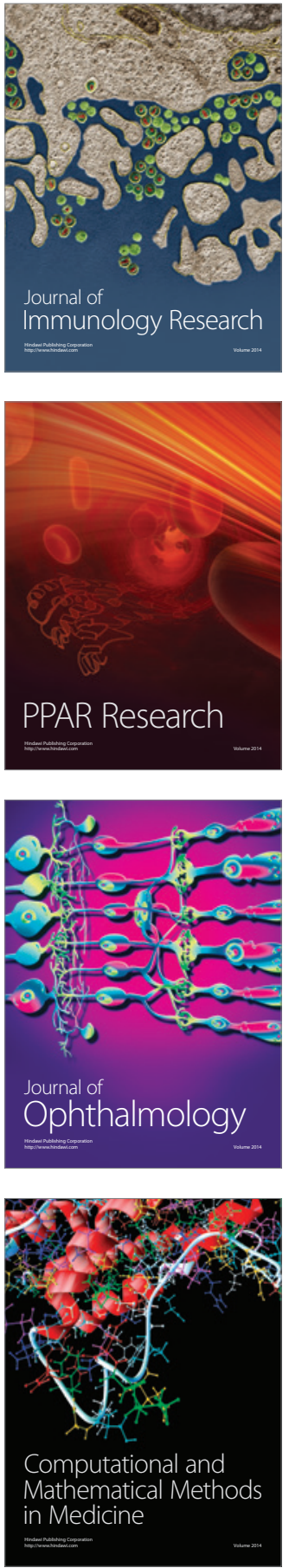

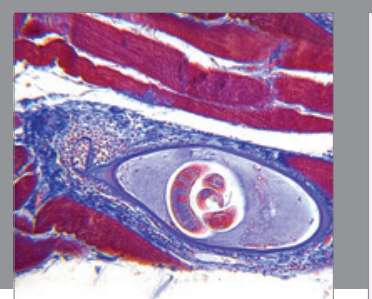

Gastroenterology Research and Practice

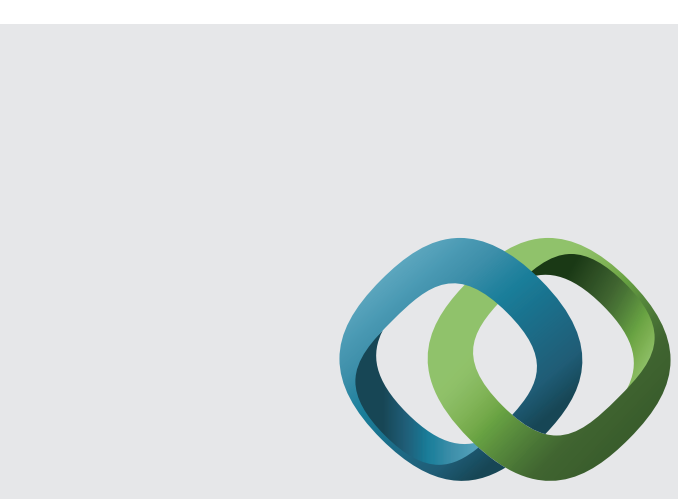

\section{Hindawi}

Submit your manuscripts at

http://www.hindawi.com
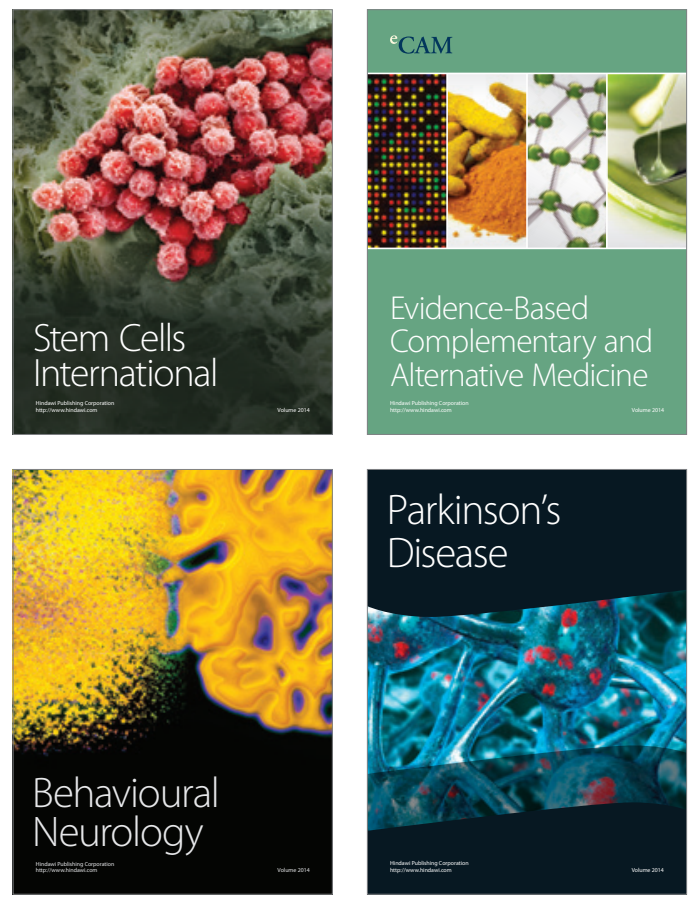
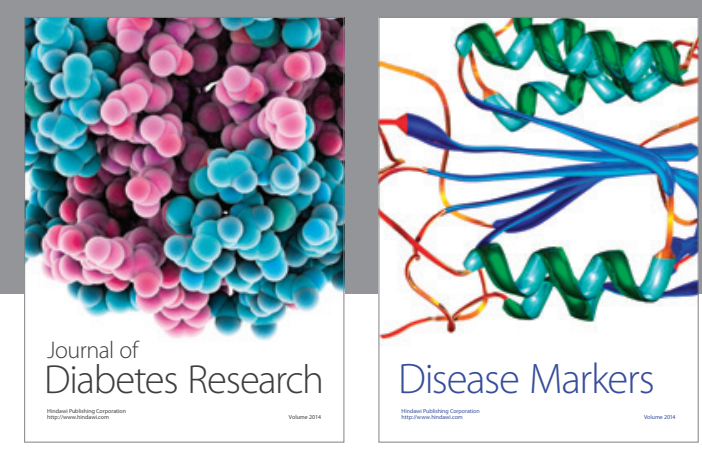

Disease Markers
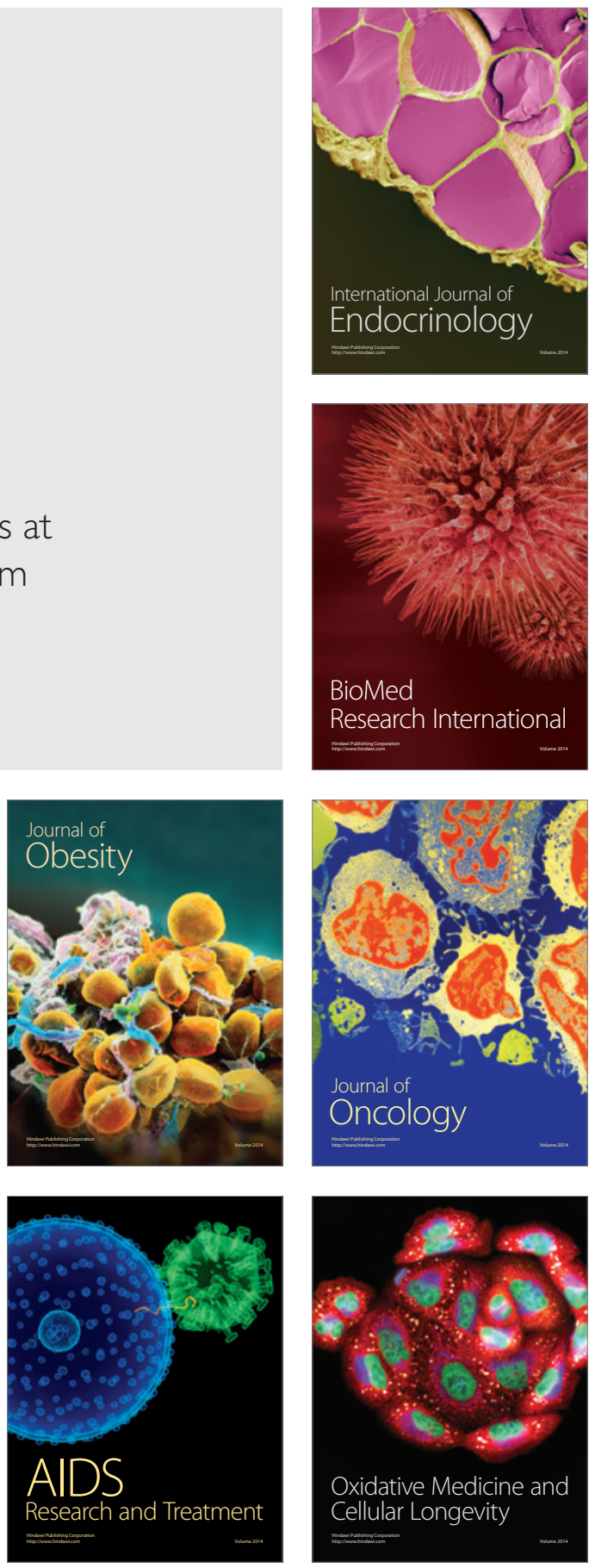